\title{
QUEST FOR POLITICAL STABILITY: PARTY LEADERSHIP ROLE IN CA Purushotam Marattha*
}

\section{ABSTRACT}

The political parties of Nepal have never been able to move as an engine of social transformation process, much like their inability to give a stable government. After replacing the Party-less regimes, with the multiparty system the country has mainly witnessed drawbacks of parliamentary system. The political parties have failed to promote democracy and they have hammered on the root of constitution.

However, a new constitution was demanded through a Constituent Assembly (CA) and after nearly a decade long exercise, the constitution of Nepal, 2015, was promulgated on September20, 2015. Since that period Nepal has formally entered into a Federal Republican Nation. The new constitution has covered all the achievements of Second People's Movement (SPM).Since then the federal republican constitution has been completely setup in Nepal.

This constitution has institutionalized the federal democratic republican setup and it has opened the rooms for amendment, whereas the constitution of the Kingdom of Nepal, 1990 was not amended even a single article for the last many years. Writing the constitution through the CA was a great achievement of Nepal. During the constitution declaration period major political forces like Big-3 NC, CPNUML and UCPNM showed their highest degree of Unity. The new constitution was passed by more than two thirds majority in the CA. But the Conflict about the number of States (Pradesh) is hampering the stability of the present new constitution.

The dissolved CA-2 has not been able to settle all the political conflicts. The on going Madhes agitation deepen into the another constitutional crisis. Tarai based parties like Samyukta Loktantrik Madhesi Morcha (SLMM), an alliance of four parties has joined the parliamentary process. Earlier SLMM has obstructed and paralyzed border area with an unseen support of southern neighbor. Daily general strike of SLMM and closure of industries at border points has led to soft state syndrome in Nepal.

Key Words: Constituent assembly, constitution, political stability, party leadership, federalism, republic.

* Dr. Marattha is Reader in Political Science at R.R. Campus, T.U., Kathmandu, Nepal 


\section{INTRODUCTION}

Nepal is situated in highly strategic areas between larger and more powerful neighbors. Nepalese geopolitical situation is very challenging because of its obstacles created by the landscapes. The country is divided into mountain, hill and Terai. The diverse geographical situation of the country is the consequence of the landlocked state. In 1971 twenty-five countries, including Nepal, were identified as the 'least-developed' in the world (Blaikie, 2001). They highlighted Nepal as an underdeveloped and slow-moving nation. Nepal is surrounded by India specially from the south, east, and west and there is China on the north. Due to this geographical situation, Nepalese people are suspicious from the southern neighbor of their interference in Nepal's domestic affairs.

When the new constitution was promulgated in the country, immediately Madheshi parties had supported the unofficial blockade imposed by the Southern neighbor. Despite this fact, Nepal seeks Chinese support on various issues. Periods of history shows that Nepal has had to face declared and undeclared blockade by India at different points of time. But our leadership never raised voices against such behavior of India. They have always tried to use middle way to please India.

\section{GEOSTRATEGIC SITUATION}

"Nepal is a Yam between two boulders. Friendly relations should be maintained with both China and India. Do not engage in offence with them. Fighting, if it is a must, should be on a defensive basis only" said P.N. Shah the Great (Rose, 1970). This was a classical definition of geopolitical situation. Thus, Nepal never engages in an offensive attack. It always makes strategies of defensive basis. Nepal must, by necessity, formulate strategies and policies that reduce their vulnerability and exploit opportunities. In crisis situations, the objective is not merely the advancement of national interests but, not infrequently, the survival of the society as an independent polity. On several occasions Nepal has had to face external threats in which the engagement of the central Himalayan region by political systems to the north or south appeared to be the issue at stake (Vaidya, 1996).

Nepal occupies a multiethnic, multilingual, multicultural population lying between the over populated country like India and China. Similarly, highest mountain of the world Mount Everest and many cultural monuments are also in Nepal. The perimeter of the greater Nepal extending from Tista on the east to Sutlej on the west was 4,079 kilometers, east-west length as 1,373 kilometers and its area was 204,917 square kilometers. It was even bigger when the country's boundaries had extended from Tista on the east to Kangara on the West and to the 
confluence of the river Ganges and Yamuna on the south with the total perimeter stretching to 5,119 line kilometers, east-west length as 1,415 km and the total area as 267,575 square kilometers. But the modern Nepal has an encircled boundary line of 3,222.88 kilometers covering an area of 147,181 square kilometers (Shrestha, 2003).

Kathmandu's role in all aspects of Nepali politics is vital and usually determinant (Joshi and Rose, 2004). But in the recent time Kathmandu is losing its capacity to deliver its services. Political turmoil in Terai has created hardships since the Promulgation of its new constitution 2072. Geostrategic position of Nepal is not favorable to make our economy self-sufficient. Unofficial and official blockade imposed by India in different periods of the history had badly hit our economy. Due to our geostrategic situation we have to select next best alternatives for an independent economy. If we cannot take any lessons from the past and present, no doubt that we will be victimized from the southern neighbors again in future.

\section{MAOIST INSURGENCY}

The Maoist movement started when the multiparty democracy was implemented full-fledged due to which the democratic constitution was hammered by the extreme force. The rise of insurgency posed a great threat to a country. The leading political parties NC and UML were in power. They were involved in the power game. The Maoist insurgency in Nepal took almost sixteen thousand lives of people. A number of thousands have been injured and displaced, and millions of Nepalese lives have been affected psychologically, economically and led politically dead, displaced and disappeared. Maoists had control a number of districts. Since 1996, under their ten year of insurgency the country deepened to a in crisis.

The ten year insurgency ended in 2006 and led to the country's transition from monarchy to republic. It abolished the nearly 3 century old monarchy. The key demand of the Maoists was a republican country with a new constitution through CA. The Maoists launched the insurgency when the parliamentary democracy existed. Their overall objective was to form a communist state. The other prominent issues raised by the Maoists included class inequality, issues of the marginalized ethnic and caste groups, women's rights, and nationalism, with their concerns about the sovereignty of the Nepali state (Lawoti, 2007). Maoist never demanded secession. Their demands were self-determination, autonomy, federalism, republic and new constitution for Nepal.

Currently, Maoist parties have been divided into five different factions. Prachanda led UCPNM, Mohan Baidhya led CPN-M, Mani Thapa led Revolutionary Communist Party, Matrika Yadav led CPN 
(Maoist) and Netra Bikram Chand led CPN Maoist. All these parties want to grab the power. Maoists always use new slogans and they have been selling their slogans based on ethnic identity. Caste based politics are tagged within their party. They adopted political competition within a socialist system. Their most significant political shift has been a conditional acceptance of multiparty democracy and they abandoned central tenets of their people's war strategy which has been a great paradigm shift in their politics.

Maoist's decision to defend the achievements of 1990 mass movement was also a major turning point. Nepali people were frustrated by the inability of the political leaders to deliver and confused by the growing strength of the Maoists (Riaz and Basu, 2010). After the April 2006 mass movement, which forced the king to relinquish power, the Maoists have tried to present a moderate image of the communists though they have done little to change their militaristic approach to politics (International Crisis Group, 2007). When the Maoists led government, Prachanda was in power and he attempted to dismiss the Army Chief which led disruption of balance of power between Prime minister and President raising a dispute in 2009. During that time the state did not fail but questions were raised against the legitimacy of the government. Similarly, when Baburam led government was in power, the first CA did not work properly. Maoist's role was not satisfactory to make the constitution within the given period. UCPNM was successful in armed revolution but they failed to manage democracy.

\section{CONSTITUTION FOR PEACE}

On 20th September, 2015 the constitution was promulgated for Nepalese people from the CA. The federal republican constitution has been made by the people's representatives. After eight years of not debate, they made their own constitution without any outside intervention. This is the first time they exercised their sovereign power. Constitution of Nepal has made a provision for multiparty, competitive, federal democratic republican parliamentary system of government based on plurality.

The recently promulgated new constitution gives space to all Nepali people for uniting and protecting the country, but some the Madhesi and Tharu groups have launched agitations demanding for identity based provinces. Their demand for identity based provinces with total autonomy creates a seeds of another conflict in the forthcoming days. If we see the example of the American Constitution, the United States was successful to make constitution through the constitutional convention in 1787 and ratified by all the existing states (Mclean, 1996). The United States Constitution that emerged from the convention established a federal 
government with more specific powers. The new constitution of Nepal has also established a way for a culture of coalition and cooperation among the major political forces of the country. The constitution of the Indian Republic is the product not of a political revolution but of the research and deliberations of a body of eminent representatives of the people who sought to improve upon the existing system (Basu, 1998: 3). Similarly, the constitution of Nepal is giving power to the federation, provinces and the local level based on the principles of cooperative, coexistence and coordination. In the beginning the major forces of Nepalese politicians showed the highest degree of unity and remained in one place like American spirit of compromise.

Nepalese constitution is short, general and fixed. It reflects the nation's value. Citizenship, fundamental rights and duties, directive principles and policies, federal, provincial, and local level provision, national security, political parties and emergency power and many other provisions are mentioned in the present constitution. The constitution has prescribed the duty of every person to uphold the constitution of Nepal. It established the character and conception of its government laying the basic principles, to which its internal life is to be regulating, distributing and limiting the functions of its different departments and prescribing the existing exercise of sovereign powers (Campbell, 1979).

The CA made federal democratic republican constitution of Nepal, with the approval of two thirds majority in the 601 members CA, endorsed by 537 lawmakers. More than a two thirds majority in the CA has taken ownership for the constitution of Nepal, 2015. This constitution is trying to end all forms of discriminations and oppression created by the feudal, autocratic, centralized and unitary system of government in the past. Under this constitution Nepal is an independent, indivisible, sovereign, secular, inclusive democratic, socialism-oriented federal democratic republican state (Constitution of Nepal, 2015).

The constitution has expressed commitment to create the bases of socialism by adopting democratic norms and values. The constitution also guaranteed multi-party democratic governance system, civil liberty, fundamental rights, human rights, adult franchise, periodic elections, complete press freedom and an independent, impartial and competent judiciary, and rule of law. CA made constitution, requested the people to uphold for ownership. This constitution also guaranteed independence, sovereignty, territorial integrity, nationality, and autonomy. Similarly in the name of national interest the constitution has a provision of boundaries protection. Agitating Madhes based parties are opposing the CA made constitution. The South's agenda is to declare the entire Terai plains as one province (People's Review, Jan.-Feb. 2015). Madhesi leaders and Madhes 
centric parties are doing their activities in the border. Indian Ambassador to Nepal Ranjit Rae clarified that India assisting the Madhes-centric parties in their protest and their border blockade were untrue (TKP, Nov. $5,2015)$. But undeclared border blockade by India created humanitarian crisis in Nepal.

The provisions for marginalized ethnicities in the new constitution have ensured equal rights for people whether they are from the hill or the Terai. The new constitution does not discriminate against Madhesh. Quest for political stability is new dependent upon major parties like NC, CPNUML, and UCPNM etc.

The Federal Democratic Republic of Nepal has three main levels of structure: federal, provincial and local. The geographical divisions of 7 provinces provisioned in the new constitution are as follows:

\section{Province No. 1}

1. Taplejung 2. Panchthar 3. Ilam 4. Sankhuwasabha 5. Terhathum 6. Dhankuta 7. Bhojpur 8. Khotang 9. Solukhumbu 10. Okhaldhunga 11. Udayapur 12. Jhapa 13. Morang 14. Sunsari.

\section{PROVINCE No.2}

1. Saptari 2. Siraha 3. Dhanusha 4. Mahottari 5. Sarlahi 6. Rautahat 7. Bara 8. Parsa.

\section{ProvinCE No.3}

1. Dolakha 2. Ramechhap 3. Sindhuli 4. Kavrepalanchowk 5. Sindhupalchowk 6. Rasuwa 7. Nuwakot 8. Dhading 9. Chitwan 10. Makwanpur 11. Bhaktpur 12. Lalitpur 13. Kathmandu.

\section{ProvinCE NO. 4}

1. Gorkha 2. Lamjung 3. Tanahu 4. Kaski 5. Manang 6. Mustang 7. Parbat 8. Syanja 9. Myagdi 10. Baglung 11. Nawalparasi (East of Bardaghat Susta).

\section{PROVINCE No. 5}

1. Nawlparasi (West of Bardaghat Susta) 2. Rupandehi 3. Kapilbastu 4. Palpa.

5. Arghakhachi 6. Gulmi 7. Rukum (Eastern part) 8. Rolpa 9. Pyuthan 10. Dang 11. Banke 12. Bardiya.

\section{ProvinCE No. 6}

1. Rukum (Western part) 2. Salyan 3. Dolpa 4. Jumla 5. Mugu 6. Humla 7. Kalikot 8. Jajarkot 9. Dailekh 10. Surkhet.

PROVINCE No. 7

1. Bajura 2. Bajhang 3. Doti 4. Achham 5. Darchula 6. Baitadi 7. Dadeldhura 8. Kanchanpur 9. Kailali. 
Some Madhesis and Tharuhat are dissatisfied with the above7 province demarcation adopted by the major parties in the newly promulgated constitution. But the government has agreed to revise the boundaries, if the agitating parties take ownership of the constitution. Dissatisfaction with the state level politics has been the growth of subnational forces. Sub-nationalism weakens the unity and integrity of the country (Saez, 2002). In federations separate constitutions for the national and federal government is required. The country cannot replace the CA made constitution but the agitating Terai forces should show political commitment on provincial boundaries, demarcation of election constituencies, proportional representation and citizenship.

\section{THE FAULT LINES}

Earlier, rulemaking, rule application and rule adjudication body was so weak, that's why the state became soft. Internally and externally various factors played roles to weaken the state machinery. The constitution of Nepal has so many fault lines. Implementation of the Nepalese constitution is impossible without drafting codification of law. Government has identified 138 laws, a majority of them relating to federalism, that need to be enacted for enforcing the provisions of the new charter (TKP, Nov. 9, 2015). Without amending these identified laws, constitution cannot be complete.

\section{POLARIZATION AFTER CA DISSOLUTION}

Nepalese political parties were polarized when the constitution was made. The state restructuring process was opposed by Terai based parties. After the promulgation of the constitution, political deadlock in Terai continued with some voice of secession. Due to the conflict in Terai, Nepal is falling in a never-ending instability. "One Terai policy" has created a problem.

Madhes based political parties have entered into a new conflict. Agitating Madhes parties are trying to bring new power to rule and lead in a country as a best alternate force. Internal polarization within the parties divided them in many fault lines. When Nepali politicians get into power they follow pro-Indian policies, when they are out of it they become antiIndian (Marattha, 2059). In this way polarization between pro and antiIndian concept has continued since independence. As the internal disputes deepen in the country, the ruling government wants to institutionalize the anti-Indian sentiment in Nepal to divert the people's attention from the National issue. If Nepal tilts with India or China, sooner or later means inviting blockade or embargo. A tiny country like Nepal can never challenge the regional power of India or China. 
Nepalese people whether they belong to Terai or Hill should live in peace and harmony. Otherwise, unnecessary activities may lead conspiracies. According to Machiavelli, a state has to try and augment territory and power for itself. It had to look upon its neighbors as actual or potential enemies (Mukherjee and Ramaswamy, 1999). Burning an effigy and national flag of neighboring countries has not solved the issue samicably. Recently, social medias were flooded with anti-Indian sentiments and slogans such as "back off India" from citizens who are agitated by the unofficial blockade. To counteract such sentiments, a small 'Back off China' rally was also staged in Terai. This type of demonstration is not a good gesture. Cat-dog type of relationship in the border is danger one for the stability of Nepal. Madhes- based parties have accused other parties as their enemies. They have accused the government and the ruling parties of inviting another disaster by seeking China's help (THT, October 29, 2015). In this way the agitating Madhes parties are giving undue favor to the blockade imposed by India. But they are against the seeking support of China. China's support to ease supplies of essential commodities is against their movement. Agitating Madhes based parties staged sit-in protests at the no man's land on the Nepal-India border to block their own motherland.

People-centric Indo Nepal reservation relations have a good gesture rather than state-centric. India has shown towards the CA made constitution. A similar action was seen in Sri Lanka. India's determined action to influence the course of ethnic politics in Sri Lanka does not accept the existence of a separate Tamil state Eelam on the grounds that it would neither serve regional nor national interest of India (Baral,1990).

\section{INDIAN INFLUENCE IN CA}

Indian Foreign Secretary S. Jaishanker was deputed in Nepal as a special envoy to PM Narendra Modi trying to hold the promulgation of newly constitution through CA. Indirectly India said that various issues remained to be solved through dialogue (Republica, September 21, 2015). South block disrupted the supply of essential goods to Nepal. Gradually, Nepal entered into a humanitarian crisis. Gradually, Nepal and India are trying to sort out the issues through the dialogues at various levels.

\section{LOCAL ELECTION HAS NOT BEEN HELD FOR LAST 18 YEARS}

Local level election has not been held in Nepal for the last 18 years. The local level development activities have been hampered for the last two decades. Without an elected body all the development process has turned into stagnant situation. People have felt the importance of local authority. On 25 April 2015 earthquake and its aftershocks left general 
people feel the urgency of this authority? People are suspicious of the political parties and their intentions are being heavily questioned for delaying local elections.

\section{AN AGENDA FOR CA}

On 27, May 2012, the Supreme Court gave direction to set the dateline either to deliver constitution or dissolve the CA. Without delivering a constitution the first CA was dissolved to obey the apex court order. Due to that event political case entered into the court room. Thus, the stability was lost. The election for the second CA was held in 2013 and Nepali Congress (NC) emerged as the largest political party in the CA. Communist Party of Nepal (CPN-UML) got second position while Unified Communist Party of Nepal UCPNM party was positioned third in the elections. Earlier, in the first CA the UCPNM was the largest party.

In the Second CA, UCPNM turned into 3rd rank and this party did not easily accept the election result. In second CA, various players especially radical parties and Terai based regional parties are trying to implant communal provinces for destabilizing Nepalese politics. After the major earthquake of April 25, the CA has started the constitution making process rapidly. The political parties have so far been able to reach a compromise on the constitution of Nepal, 2015. The new national Charter of Nepal has become one of the youngest republics and the 25th nation to write the constitution through elected representatives (TRN, September 21, 2015).

Earlier former PM Sushil Koirala agreed that he would step down as PM after the new constitution was delivered (THT, June 1, 2015: 5). But he failed to fulfill his commitment, and so NC failed its public trust. The NC contested in the PM election which was against the consensus among the 3 major parties. Agitating Madhes based parties boycotted the CA. Madhesis could not take any ownership of the constitution making process. The agitating groups of Madhesi and Tharuhat quit from statute process. In democracy each and every party has their right to participate and refuse.

\section{ETHNIC NATIONALISM}

Nepal is a multi-ethnic, multi-lingual, multi-religious, multicultural nation. Nepalese people are living in diverse geographical regions and being committed to and united by a promise of loyalty to national independence. More than hundred and twenty five indigenous nationalities are in Nepal. All their mother tongues are different. Only one caste and class cannot have a monopoly in the state power. The pattern of political 
demands by organized groups appears to have been repeating every ten years for the last six-seven decades (Bhattachan, 2000). After the promulgation of the constitution, Madhes uprising got momentum. Ethnic nationalities like Tamang, Newar, Limbu, Rai etc. can raise their voices at any time, if they feel that the country has not given them any justice. Ethnic nationalism of Nepal is very sensitive. The major parties like NC and the CPN (UML) are against ethnic based politics. They are in favor of minority's protection in constitution.

Nepal has never played a discriminatory policy against Madhesi in the constitution. Actually Nepalese state has never shown unequal treatment with any caste and ethnicity, because Nepal is a home of more than hundreds indigenous nationalities (Shrestha, 2007). Ethnicity-based state building is not durable because, it carries seeds of conflict. Nepal exists when the all ethnic nationalities consider forming a nation. All the nationalities of Nepal have participated in the various movements against feudal, autocratic, centralized and unitary system in the past and are trying to end all forms of discriminations now.

\section{NATION-BUILDING AND FEDERALISM ISSUE}

Nation-building and constitution-making process provides some legitimacy for state-building. Third world governments are building nations in support of their states (Mclean, 1996). Rise of Nationalism sweep the changes of a nation. Nationalism and nation building are not separable with each other. Leader of the political party should pay attention in nation building process. Ethnic based federalism creates a great polarization in the major political parties.

Federalism exists when (1) two levels of government rule the same land and people, (2) each level has at least one area of action in which it is autonomous, and (3) there is some guarantee of autonomy of its own government in its own sphere (Kalin, 1992). The opponents and supporters of federalists have turned the country at crossroads. In federal states the powers are allocated by the constitution. Distribution of powers between the federal government and the constituent units can be designed to achieve the objectives. Loosely defined federalism in present constitution is just like a high-sounding. It is not a time of reviewing the success and failure of newly made constitution of Nepal.

Nepal is a multi-ethnic, multi-lingual, multi-religious, and multi-cultural characteristic. People of Nepal are living in diverse 
society and culture. Polarization between federalists and their opponents are getting larger. The Ethnicity based federation will create problems for the integrity of the nation-building. State restructuring on the basis of ethno-based identity is not suitable for Nepal. As a multilingual society, Nepal should not have sided with any ethnic community for its nation building. Federalism is to be a way out of Nation building rather than disintegration.

\section{POLITICAL CRISIS}

Political parties of Nepal have never been able to move constitution as an engine for social transformation. Nepalese democracy has been not developed as an institutional concept. After six periodic experiments of constitutions Nepalese people have got a 7th statute from CA. CA was ended after the promulgation of the constitution.

Agitating Madheshi parties have been initiating war against the newly born constitution of Nepal. Constitutional debate is not yet ended, because the CA made constitution is also carrying a lot of conflict. Disgruntling Madhes base parties paralyzed normal life of the country when the constitution was promulgated from the CA. Since that period India also unofficially imposed blockade in Nepal to favor on Madhes base parties.

\section{CONCLUSION}

The constitution of Nepal 2015 was made by the CA. Earlier, the country's top leaders had postponed the CA for an indefinite period. Parties had not been able to forge consensus neither in the first CA nor did it seem on the Second CA. Sovereign Nepal got a new constitution through people's representative. The constitution was endorsed by CA, authenticated by CA chairman and promulgated by the then President Ram Baran Yadav on 20, September, 2015. But the agitating Terai based parties have been opposing the new constitution. Seeds of conflict have been planted in this constitution.

Terai based parties are playing a foul play for breaking the constitution and assisting the southern neighbors who has been pressurizing blockade in Nepal. This blockade is against Nepal and Nepali people. India's unofficial blockade in Nepal has hit general people's lives hardly. Massive cultural impact from southern is getting a setback for the Nepali nationalism.CA made constitution hopes to rebuild our nation with a great feeling of patriotism. 
The new constitution ensures all the people for their life, liberty and property. It is also a broadly accepted document by all Nepalese within the nation. The constitution cannot bring any peace and prosperity in the country if the Terai is still in unrest. Only the commencement of the constitution is not enough. The ownership of all the people should be present to make a complete constitution. Major parties failed to gain support from Terai. The boundary issue has not been solved yet. There is a great understanding of major 3 parties for their grand decisive role in CA2. During the last 8 years of constitutional experiment, political leaders of Nepal have shown their broad consensus on the promulgation of the constitution. As the constitution was the result of Nepalese dream for the last 70 years, people were expecting that the new constitution will ensure peace and political stability in the country.

CA made constitution is the fundamental law of Nepal. The Federal Democratic Republic of Nepal has three main levels of governance: federal, provincial and local. The State powers are to be used by all three levels. This provision in the constitution will protect Nepalese national interests. Under this provision 7 provinces are mentioned.

The multi-party competitive democratic republic and federal system of governance, human rights and fundamental rights, rule of law, separation of powers and check and balance, equitable society based on plurality and equality, and inclusive representation and identity are also mentioned in the present constitution of Nepal. The present constitution is trying to end all forms of discriminations and oppression created by the feudal, autocratic, centralized and unitary system at the different period. This is not the time for destructive criticism, not the time for blaming each other, but it is the time to implement the CA made constitution without any biases. Constitution will not be stable if there is no provision of amendment.

\section{WORKS CITES}

Baral, L. R. (1990). Regional Migrations Ethnicity and Security: The South Asian Case. New Delhi: Sterling Publisher.

Blaikie, P.M., John Cameron and Seddon, John David (2001). Nepal in Crisis: Growth and Stagnation at the Periphery. Delhi: Adroit Publishers.

Basu, Durga Das (1998). Introduction to the Constitution of India. New Delhi: Prentice Hall of India. 
Bhattachan, K.B. (2000). "Possible Ethnic Revolution or Insurgency in a Predatory Unitary Hindu State, Nepal." Domestic Conflict and Crisis of Governability in Nepal. Kathmandu: CNAS, p. 136.

Shrestha, Buddhi Narayan (2003). Border Management of Nepal. Kathmandu: Bhumichitra Co. P. Ltd.

Campbell, H. (1979). Black's Law Dictionary (5th Ed.). USA: West Publishing Co.

Constitution of Nepal (2015). (2072). Kathmandu: Kanoon Kitab Bywastha Sameeti (Law Book Management Committee).

International Crisis Group (2007). "Nepal's Maoists: Purists or Pragmatists." Asia Report No. 132-18, May, 2007 p. 1.

Joshi, Bhuwan Lal and Leo. E. Rose (2004). Democratic Innovations in Nepal: A Case Study of Political Acculturation. Kathmandu: Mandala Publications.

Kalin, W. (1992). "Decentralized Government and Devolution of Powers: Lessons from the European Experience?". Essays on Constitutional Law. Vol. 12, Kathmandu: Nepal Law Society, p. 47.

Lawoti, Mahendra (Edited) (2007). Contentious Politics and Democratizations in Nepal. New Delhi: Sage Publications.

Mahat, R.S. (2005). In Defence of Democracy. New Delhi: Adroit Publishers.

Marattha, Purushotam (2059 B.S./2002 A.D.). International Relations (2nd reprint). Lalitpur: Sajha Prakasan.

Mclean I. (ed.) (1996). Oxford Concise Dictionary of Politics. New York: Oxford University Press.

Mukherjee, Subrata and Sushila Ramaswamy (1999). A History of Political Thought. New Delhi: Prentice Hall.

Riaz, Ali and Subho Basu (2010). Paradise Lost: State Failure in Nepal. New Delhi: Adarsh Books.

Rose, Leo E. and Fisher, Margarett (1970).The Politics of Nepal. USA: Cornell University Press.

Sali, M.L. (1998). India China Border Dispute. New Delhi: A.P.H. Publishing Corporation.

Saez, L. (2002). Federalism without a Centre (2002). New Delhi: Sage Publications.

Shrestha, B.G. (2007). "Ethnic Nationalism in Nepal and the Newars". Contentious Politics and Democratization in Nepal. New Delhi: Sage Publications. 
174 QUEST FOR POLITICAL STABILITY ...

The Kathmandu Post. Nov. 5, 2015, p. 1.

The Himalayan Times. June 1, 2015, p. 5.

The Rising Nepal. September 21, 2015, p. 1.

People's Review. June 11-17, 2015 p. 25.

Vaidya, T.R. and B.R. Bajracharya (1996). Nepal International Perspective. New Delhi: Anmol Publications Pvt. Ltd. 